\title{
The Credit Crunch and the Digital Bite
}

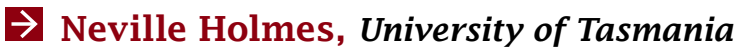

\section{Use of digital technology caused the present financial turmoil.}

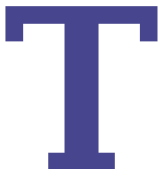

he title of a recent article in The Guardian asked "Was software responsible for the financial crisis?" (www.guardian. co.uk/technology/2008/oct/16/ computing-software-financialcrisis), although the first sentence more properly blamed "the analysts who built the computer software that drove the derivatives markets that, in turn, drove the financial collapse." Although these analysts-quantitative analysts or quants for short-are mostly physicists or mathematicians rather than computing professionals, the credit crunch has many implications for our profession.

\section{FINANCIAL SYSTEMS}

Banks and other financial institutions work by transferring and otherwise manipulating money. The modern financial systems used by the employers of quants harness modern digital technology to work with money of various kinds, and in increasingly diverse ways. The Internet makes it easy for money of different kinds to be bought and sold, to be sent and received, and to be amplified and hidden away.
In the early days of automatic data processing, banks and insurance companies were important users of digital machinery. The banking industry put an enormous effort into developing the automatic machinery for processing checks that had data encoded in the familiar MICR fashion, now half a century old. This fostered the growth of commercial banking, and was followed by other financial machinery and processes now familiar in initialisms such as ATM and EFTPOS.

\section{The rise of finance}

At the same time, other financial enterprises have exploited digital technology in various ways and have flourished through this use. In the US, the financial industry's share of the stock market had risen to nearly a quarter in 2007, up from a twentieth in 1980. It would be reasonable to say that this was only possible through use of modern digital technology.

International currency trading is another area where digital technology has played a huge role, with a huge market both black and white. If the tax on such trading suggested as a control measure by US economist James Tobin in 1978 were set at one basis point (jargon for one hundredth of a percent), the revenue would be around $\$ 70$ billion a year (www. guardian.co.uk/commentisfree/2008/ oct/15/economics-economy).

Digital technology has allowed money to be dealt with automatically and swiftly in amounts both huge and small. This dealing is simply data processing because money nowadays is simply digital data.

Data processing at the private level lets people more conveniently buy goods and services; at the retail and wholesale enterprise level it allows more convenient selling and buying of goods and services; and at the production and manufacturing level it allows more convenient selling of goods and services.

\section{Unhitched from reality}

Beyond these levels, financial data processing permits transactions that have nothing to do with goods, little to do with services, and can be carried out blindingly fast with any amount of money. The financial industry's growth has come about through the proliferation of the financial processes and instruments made possible by modern digital technology.

Much of the talk about repairing the failing financial system has concentrated on forbidding or limiting Continued on page 90 
certain kinds of financial transactions. For example, the Tobin tax, originally suggested to smooth out exchange-rate fluctuations, has been put forward as a means of exposing or preventing the use of tax havens and other means of camouflaging money. The problem with seeking to control processes is that it's quite easy for quants and their ilk to work out new processes, which leaves the would-be controllers always chasing a moving target. the pound as their basic unit of currency still maintained 240 pennies to the pound.

\section{Heavy metal?}

Coinage's usefulness depends on the maintenance of its perceived value. In William's time, and for a century or two after, monetary transactions were fairly limited, so there was no depreciation. By Elizabeth I's time, however, 240 pennies held only a quarter of a pound of silver, which
To understand the credit crunch we must understand what money has become and how.

\section{A SHORT HISTORY OF MONEY}

What is being processed is money. To understand the credit crunch we must understand what money has become and how.

\section{Better than barter}

Money originally had to with avoiding the inconvenience of bartering goods. Setting up some intermediary goods-such as cowrie shells-with inherent numerality let goods be given or taken amicably by exchanging them for an agreed quantity of the intermediary.

Developing civilizations enjoyed a clear advantage in having this intermediary be durable, portable, and valuable in its own right. In Asia Minor over two millennia ago this led to coins being made out of gold and silver, valuable metals that were both durable and, given their density, portable. The numerality was credibly achieved by having the coins officially issued with a stamped inscription identifying their weight.

The convenience of coinage meant it was widely adopted. For example, about a millennium ago in England, William the Conqueror issued silver pennies weighing one-240th of a pound. Until recently, countries using brought England into disfavor with other countries. This official depreciation is called debasement.

As the use of coins increased, so did fraud of various kinds. The wear and tear of frequent use made it possible to remove metal inconspicuously. New coins therefore had more inherent value than old, so they were from time to time officially debased to prevent new coins from being melted down. Elizabeth brought this process to a halt by a complete recoinage in 1560-1561 and, apart from one quite minor case, there was no debasement until 1931

This is just a glimpse of coinage's early history. There were many complications and vicissitudes, such as the varying use of gold and silver in different countries, the varying availability of gold and silver bullion, and political activities such as conducting wars and their financing.

However, there is more to money than coins. Their increasing use meant not only that more people used them, but also that transactions needed more and more coins. Banks overcame this inconvenience by holding coins or bullion safely for depositors, who were issued with bank notes that recorded their entitlement to their deposits.

\section{Duly noted}

The establishment of banks led to traffic in bank notes. Depositors could pay debts using their bank notes, and the banks could use those notes in reverse to lend money on the basis of their having coinage on deposit sufficient for the day-to-day needs of both depositors and borrowers. In this way, the amount of money in circulation was no longer directly tied to the amount of bullion on deposit, but to the total of the bank notes on issue. This decoupling could and did badly affect prices.

Governments mainly avoided these bad effects by limiting the issue of notes so that the potential for converting a bank note into bullion was preserved. The two political controls involved-on convertibility and on the issue of notes-were variously applied and typically reapplied after relaxation led to depression and depreciation.

\section{Forced conversion}

A further complication was the rise of international transactions that required conversion of money from one currency to another. Such conversion problems led to the international Bretton Woods agreement at the end of World War II. This linked international exchange rates to the US dollar, which was convertible to gold (news.bbc.co.uk/2/hi/ business/7725157.stm).

All this changed in August 1971 when the US suspended the dollar's convertibility, freeing the dollar from its direct guarantee of real value. The US dollar being the world's dominant currency, this led to floating exchange rates and a huge international flow of money because the perception of its value now inevitably fluctuated. Governments had to concern themselves with adjusting to the effects of huge amounts of money moving around and changing what was seen as their intrinsic value. 


\section{Monetary explosion}

The financial industries were now able to devise a succession of monetary instruments and procedures that vastly expanded their enterprises (www.economist.com/displaystory. cfm?story_id=12415730). Currency futures trading started in 1972 and grew rapidly, followed by options trading, arbitrage, securitization, interest-rate swaps, portfolio insurance, collateralized debt and, in the past decade, credit-default swaps. By and large, regulation was reduced, starting with the abolition of capital controls and the separation of commercial and investment banking.

Changes of these kinds were accelerated by the use of digital technology, recently achieving breakneck speed. "Somehow the genius quants - the best and brightest geeks Wall Street firms could buy-fed $\$ 1$ trillion in subprime mortgage debt into their supercomputers, added some derivatives, massaged the arrangements with computer algorithms and-poof! - created $\$ 62$ trillion in imaginary wealth" (www.nytimes. com/2008/10/12/opinion/12dooling. html?_r=1\&th\&emc =th). This description is a somewhat hyperbolic account of what actually happened.

More soberly: "The total outstanding notional amount of financial derivatives, according to the Bank for International Settlements, is \$684 trillion (as of June 2008) — over 12 times the world's nominal gross domestic product." (sec.online.wsj.com/article/SB122663373660027575.html). Spread worldwide, that's roughly $\$ 100,000$ per capita. How unreal can money get?

\section{RUNAWAY COMPLEXITY}

Given that it's impractical to control the development of abstract processes and that quants can easily stay one lap ahead of the controllers, how is the world of money to be tamed? Money itself must be better controlled. Clearly, money has become far too complex by disen- gaging from real value-goods and goods-related services.

Fixed or stable exchange rates would bring some reality back to money, primarily in the international arena. However this only addresses relative values, and doesn't address the problem of setting up a direct representation of real value. Simply reverting to some form of a gold standard would do this, but it would be politically and practically impossible except maybe in stages. What might be a first stage?

In an earlier essay I suggested a way to reduce the complexity of corporate structures (The Profession, July 2003, pp. 100, 98-99). The idea was to forbid "any corporation from owning part of any corporation that owns part of any other corporation—or, more succinctly, [to limit] corporate ownership to two levels."

While adopting this simplification would tend also to simplify financial systems, the idea could also be applied to money. This would forbid money or other financial instruments from being applied to any financial instrument that doesn't directly represent real value, a modern version of placing limits on bank note issue. More succinctly, financial structures would be limited to two levels. This would eliminate the derivatives that are the credit crunch's root cause.

$\mathrm{T}$ he computing profession will all too likely be blamed for the bad results of any complex project involving computers. This has already happened with the present financial crisis, as the opening citation notes.

Two principles should be kept in mind. First, any computing system will fail in the long run if the reallife system it supports is flawed in the first place. According to an old saying, you mustn't mechanize a mess because all you'll get is a bigger faster mess. The financial crisis is just such a creature.
Second, in complex projects the computing professional should be working in partnership with members of other relevant professions (The Profession, Jan. 2007, pp. 128, 126-127). Complex projects require knowledge and experience beyond that likely to be held by a computing professional, and so responsibility should be shared.

In the present crucial situation the computing profession must work in partnership with the other professions bringing digital technology to bear on the problem. More importantly, the profession must exercise system engineering skill and professional influence to ensure that the problem being faced is properly understood by all involved in solving it. [

Neville Holmes is an honorary research associate at the University of Tasmania's School of Computing and Information Systems. Contact him at neville.holmes@utas.edu.au. 